\title{
Exploring the Implementation of Digital Tools in Online Classroom
}

\author{
Yentri Anggeraini
}

\author{
English Education Study Program, Universitas Baturaja \\ Corresponding author.Email: anggeraini.yentri@yahoo.com
}

\begin{abstract}
The COVID-19 pandemic has changed the teaching process. From face-to-face learning to online learning with various conditions/locations between learners and teachers. This research aims to explore the implementation of digital tools in online classrooms. This is a case study that explores the teaching process and classroom activities in the online teaching and learning process of students in fourth semester of the English Department. When collecting the data, the researchers used observations, interviews, and qualitative visual/digital files. The researcher considered triangulation in the way of data collection. In order to obtain the reliability of the research, the transcript check and the persistence check of the code meaning were adopted. This research reveals that the common digital tools in the online classrooms are Zoom, WhatsApp groups, and Google Classroom. It can be deduced that the common problems that learners face when presenting and listening to explanations through Zoom are internet connection, low battery power, and inability to hear during the explanation process. clear. This online learning familiarizes learners and lecturer with EFL digital media.
\end{abstract}

Keywords: Digital tools, online classroom, digital teaching, EFL

\section{INTRODUCTION}

Handling digital tools is an important thing to provide materials in this era of online teaching. They provide some useful things for the development of language skills in the research examples [1]-[4]. Moreover, [5] investigated the effectiveness of Google Classroom as an online learning platform, and the results showed that participants have a positive attitude and its ease of use, practicality and accessibility. In addition, [6] pointed out that teachers used PC, Internet and PowerPoint in language classes. Then, [7] proposed that technical users can gain new experiences through understanding, exploration and practice in the process. Technical tools are necessity in education [8].

These studies are based on the beliefs of educational practice on digital technology tools and media in language learning [9]-[16]. [17] technology makes the teaching process more vivid. Moreover, [18] argue that technology makes the English learning process more student-centered, but takes less time. Furthermore, [19] suggested that education centers need to focus on the integration and internalization of computer use as an educational tool. The learners enjoy to learn new technology in classroom [20]. It can be concluded from the research that the use of technology provides positive evidence for language teaching and learning in teacher education programs.
Online learning poses challenges for teachers and students alike. [21] mentioned that learner anxiety and problems related to external delivery models can be solved in an online environment. In addition, [22] discussed the challenges and opportunities in online learning. Sometimes the learner could not download the browser after multiple attempts, and she was using outdated equipment. Unlike previous studies, this research focuses on the implementation of digital tools (zoom meetings and WhatsApp groups) that support online learning. I hope that the results of this study can be used as an evaluation of the lecturer's preparation for online learning in the next semester.

\section{METHOD}

This case study aims to explore the implementation of digital tools in online classrooms. It explores the participants' activities during the implementation of digital tools in their studies. The researcher collected data by participating in four online classroom activities, analyzing visual documents from online teaching and learning platforms, and conducting interviews on three questions. Transcript verification and checking the persistence of the meaning of the codes were used to ensure the study's reliability. Following the steps from the previous section, the data was analyzed and evaluated [23]. 


\section{FINDINGS AND DISCUSSION}

\subsection{The Observation Result of Implementation of Digital Tools in Online Learning}

Observation results show that participants in online learning activities use some online learning platforms to handle the teaching process in each meeting. In observation 1, Twenty-six students attended the Zoom meeting. Participants and lecturer discussed the teaching materials and methods of the course. Then, they discussed the group presentation and individual presentation through the zoom meeting, and the information will be discussed on the WhatsApp Group. Most people attended the zoom meeting on time, and some of them left the zoom when the course was running for about 30 minutes. In observation 2 , the 23 students attended zoom meetings. The selected group presentation handled the class by presenting the materials. Few people were in offline video and asked to rejoin the zoom meeting. In observation 3, twenty-six students attended the Zoom meeting. The selected group presentation handled the class by presenting the materials. The listeners cannot clearly hear the speaker's voice. In observation 4 . The selected group presentation handled the class by presenting the materials. All the participants participate actively during the class presentation. It can be concluded that zoom can be used for students to express their opinions. It is in line with the result from [18].

\subsection{The Result of Interview}

Participants' views on the implementation and use of digital tools are presented in the order of the questions asked in the interview as follows:

Q1. What are the digital tools that you use during online learning?

Almost some students mentioned that they use WhatsApp groups, zoom, Facebook groups and Google Classroom for online learning.

\section{Q2. What do you think of online learning?}

Almost all students mentioned that online learning requires important preparations, such as internet facilities (connection), extra/sufficient computer or smartphone batteries. The following are the answers of some students in the interview:

"In my mine, online learning needs to prepare such a network and a good atmosphere, because it is carried out in our home and carried out when we are conducting group presentations" (IS.1)

"I think online learning is effective when both the teacher and the learner have good facilities (such as Internet connection) and there is no electricity problem" (IS.2)

"In my opinion, online learning provides me with some new platforms for learning English. This is very interesting. It prepares us for online classes. We can study at home without having to go to classes" (IS.3)

"online learning makes us familiar with new platform and we need to develop our skills to operate it so that we can follow class well" (IS.4)
From the interview results, it can be derived that online classes make us aware of technological upgrades, so as to master everything related to digital learning. In other words, we should cultivate our digital capabilities so that we can face it well. This is consistent with the research done by [24]

\subsection{The Result of Digital Documents on the Implementation of Digital Tool (Zoom)}

Some of the screenshots that showed some problems faced by the learners during the online learning through zoom meeting.

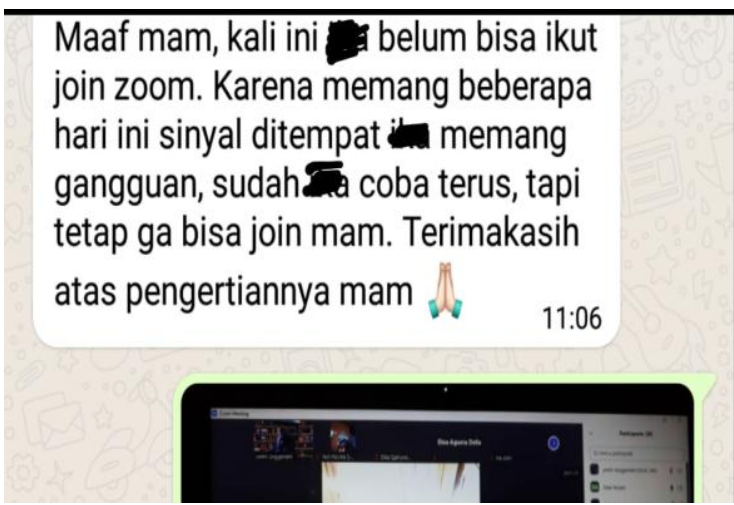

Figure 1. Problem related to signal

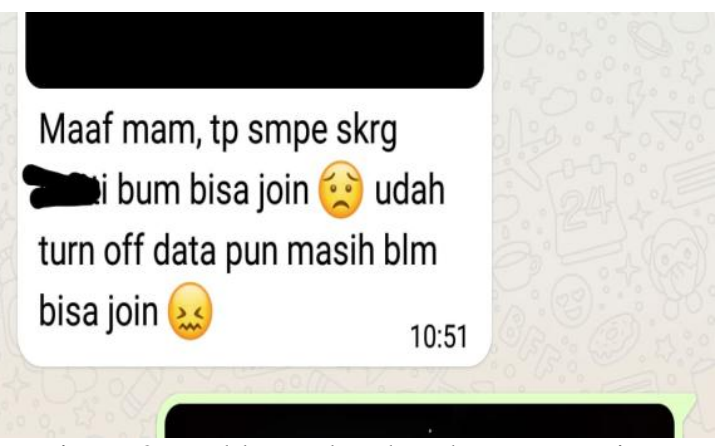

Figure 2. Problem related to data connention

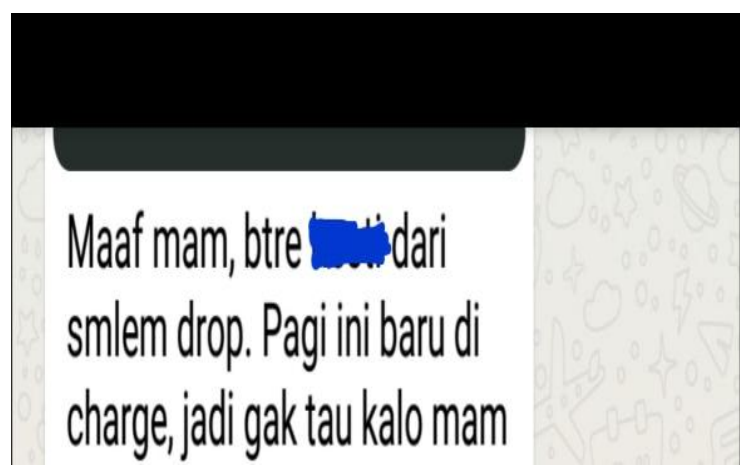

Figure 3. Problem related to low batery 


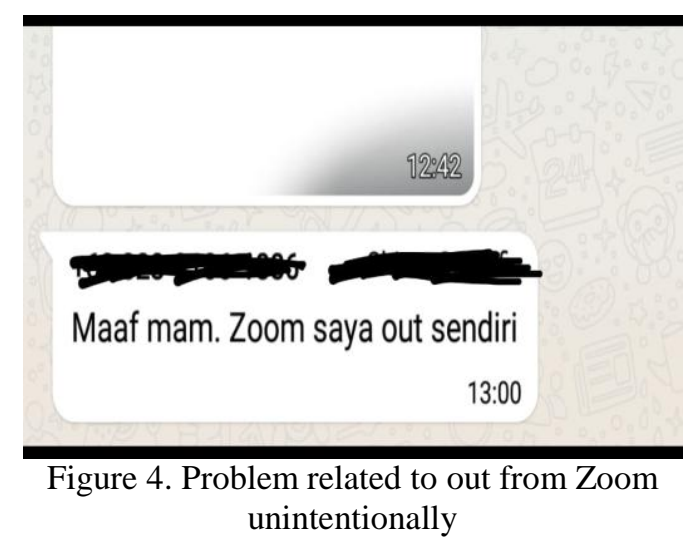

The screenshots from the WhatsApp group showed that the learners had trouble in their connections and their battery so that they cannot join the zoom well. These problems were similar with the findings from [25]. Effective and efficient use of digital tools has become a challenge for teachers [26].

From the findings, it can be concluded that the teachers and students should overcome the problems in online classroom and one platform does not work well and should be managed by other tools such as google classroom, zoom/google meet, and WhatsApp groups. The students can follow up zoom`s group discussions through google classroom forum and WhatsApp group. The recordings of the online classroom can be shared with the students to avoid missing the exchange of materials because in this study, many of students cannot fully participate on the virtual meeting in zoom. The ever-changing digital tools provides teachers to more digitally literate [27]. Both teacher and learners should improve their competencies on the latest version of digital media for teaching. They should prepare for the technology changes. New technology makes the learner enjoy online classroom [20]. In other occasion, online learning has introduced some new platforms for learning English. It is very interesting, it prepares us for online courses and we can study at home without having to attend classes.

\section{CONCLUSION}

To summarize the familiar digital tools in online classrooms are zoom, WhatsApp groups, Facebook groups, and Google Classroom. The learner argued that online learning requires preparation, such as sufficient/good computer or smartphone batteries, Internet connection, and the host should not create a good atmosphere in noisy places while presenting. The common problems that learners encounter when they demonstrate and listen to the narration through zoom are Internet connection, low battery power, and not being able to hear clearly during the narration. This online learning familiarizes learners with EFL digital media. For further research, it is very necessary to conduct research on effective teaching strategies and solutions to common problems in online learning. This study only limited observations and discussions on WhatsApp groups during the four meetings and the zoom meeting.

\section{REFERENCES}

[1] S. Bax, "Normalisation revisited: The effective use of technology in language education," Int. J. Comput. Lang. Learn. Teach., vol. 1, no. 2, pp. 1-15, 2011, doi: 10.4018/ijcallt.2011040101.

[2] H.-C. Tai, "Effects of collaborative online learning on EFL leaners' writing performance and self-efficacy," English Lang. Teach., vol. 9, no. 5, pp. 119-133, 2016, doi: 10.5539/elt.v9n5p119.

[3] Z. Hazarika, "Exploring the impact of technology in teaching English: TESOL in the context," Eur. J. English Lang. Lit. Stud., vol. 5, no. 10, pp. 19-28, 2017.

[4] N. A. Bani Hani, "Benefits and barriers of computer assisted language learning and teaching in the Arab world: Jordan as a model," Theory Pract. Lang. Stud., vol. 4, no. 8, pp. 1609-1615, 2014, doi: 10.4304/tpls.4.8.1609-1615.

[5] A. H. Albashtawi and K. B. Al Batainch, "The effectiveness of google classroom among EFL students in Jordan: An innovative teaching and learning online platform," iJET, vol. 15 , no. 11, pp. 78-88, 2020.

[6] R. Yordming, "Teachers' perspective towards digital teaching tools in Thai EFL classrooms," Int. J. Lang. Lit. Linguist., vol. 3, no. 2, pp. 4548, 2017, doi: 10.18178/ijlll.2017.3.2.108.

[7] M. C. Murray and J. Pérez, "Unraveling the digital piteracy Paradox: How higher education fails at the fourth literacy," Issues Informing Sci. Inf. Technol., vol. 11, pp. 85-100, 2014, doi: 10.28945/1982.

[8] M. Ince, "The investigation of instructors' views on using technology in English language teaching," Procedia - Soc. Behav. Sci., vol. 141, pp. 670-674, 2014, doi: 10.1016/j.sbspro.2014.05.117.

[9] S. Celik and K. Aytin, "Teachers ' views on digital educational tools in English language learning: Benefits and challenges in the Turkish context," TESL-EJ, vol. 18, no. 2, pp. 1-18, 2014.

[10] S. Sarfraz, Z. Mansoor, and R. Tariq, "Teachers' and students' perceptions of the communicative language teaching methodology in the CALL environment: A case study," Procedia - Soc. Behav. Sci., pp. 730-736, 2015, doi 10.1016/j.sbspro.2015.07.604.

[11] C. Yükselir, "English foreign language (EFL) instructors' and teachers' perceptions towards the integration of internet-assisted language teaching(IALT) into EFL instruction," J. Effic. Responsib. Educ. Sci., vol. 9, no. 1, pp. 23-30, 2016, doi: 10.7160/eriesj.2016.090104.

[12] S. Izadpanah and M. Alavi, "Student-engaged viewpoint on technology in learning English in Zanjan public high schools," Theory Pract. Lang. Stud., vol. 6, no. 4, pp. 854-860, 2016, doi: $10.17507 /$ tpls.0604.25. 
[13] B. Gorjian, "The evaluation of using computer assisted language learning (CALL) facilities in developing EFL among Islamic Azad University practitioners: The case of computer literacy," Iran. Appl. Lang. Stud., pp. 35-50, 2017.

[14] D. Jafari, A. Dabaghi, and H. Vahid Dastjerdi, "The effects of integrating ICT resources into reading comprehension in Iranian high school," Int. J. Res. Stud. Lang. Learn., vol. 4, no. 2, pp. 57-68, 2014, doi: 10.5861/ijrsll.2014.851.

[15] T. Juurakko-Paavola, H. Rontu, and M. Nelson, "Language teacher perceptions and practices of digital literacy in Finnish higher education," AFinLAn Vuosik., no. 76, pp. 41-60, 2018, doi: 10.30661/afinlavk.69640.

[16] Z. Ozer, "An investigation of prospective ELT teachers ' attitudes towards using computer technologies in foreign language teaching," $J$. Lang. Linguist. Stud., vol. 14, no. 1, pp. 328341, 2018.

[17] L. Baskaran and P. Shafeeq, "ESL teachers , perception of CALL integration in ELT," Int. $J$. Stud. English Lang. Lit., vol. 3, no. 5, pp. 63-74, 2015.

[18] S. D. Shyamlee and M. Phil, "“ Use of technology in English language teaching and learning ': An analysis," in International Conference on Language, Medias, and Culture, 2012, vol. 33, pp. 150-156.

[19] A. Sarıçoban, "Pre-service ELT teachers' attitudes towards computer use: A Turkish survey," Eurasian J. Educ. Res., no. 53, pp. 5978, 2013, doi: 10.14689/ejer.2013.53.4.

[20] L. Stosic, "The importance of educational technology in teaching," Int. J. Cogn. Res. Sci. Eng. Educ., vol. 3, no. 1, pp. 111-114, 2015.

[21] J. Gillett-swan, "The challenges of online learning supporting and engaging the isolated learner," J. Learn. Des., vol. 10, no. 1, pp. 2030, 2017.

[22] O. B. Adedoyin and E. Soykan, "Covid-19 pandemic and online learning: The challenges and opportunities," Interact. Learn. Environ., pp. $1-13$, 2020 , doi: 10.1080/10494820.2020.1813180.

[23] J. W. Creswell, Educational research: Planning, conducting and evaluating quantitative and qualitative research, 4th ed. Pearson Education Limited, 2012.

[24] Y. Anggeraini, A. Faridi, J. Mujiyanto, and D. A. L. Bharati, "The teachers' perceptions on digital literacy competences in EFL classroom," Asian EFL J., vol. 24, no. 4, pp. 5-12, 2019.

[25] V. Saminathan, "Problems of online classes," Int. J. Acad. Res. Reflect., vol. 9, no. 6, pp. 1-3, 2021, doi: 10.6084/m9.figshare.13573550.

[26] Y. Anggeraini, "Language teaching in the digital age: Teachers' views and its challenges," Reseach Innov. Lang. Learn., vol. 3, no. 3, pp. 163-172, 2020.
[27] Y. Anggeraini, A. Faridi, J. Mujiyanto, and D. A. L. Bharati, "Pre-service English teachers`views on digital literacy competences in language teaching," in Proceedings of the 5th International Conference on Science, Education and Technology (ISET 2019), 2019, pp. 453-459, doi: 10.4108/eai.29-6-2019.2290408. 